Vol. 3, No. 2 | Jul - Dec 2019

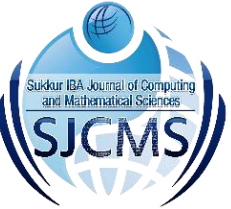

\title{
Implementation of Kanban Techniques in Software Development Process: An Empirical Study Based on Benefits and Challenges
}

\author{
Muhammad Noman $\operatorname{Riaz}^{1}$
}

\begin{abstract}
:
It has been observed that there is an increasing trend of implementing Lean Techniques as a whole in general and Kanban in particular in the software development process all across the globe to reap the proclaimed advantages of these techniques as documented in the available literature and verified by the Lean practitioners. The main goal of this paper is to highlight the present state of implementation and usage of Kanban techniques in the software development process, its obtained and to-be-obtained benefits, challenges that are being faced by the software development companies and the reason(s) of motivation that compels the organization to adopt Kanban technique. Furthermore, the solutions for challenges identified during the study will also be suggested. In order to achieve this, an empirical study has been conducted encompassing a survey followed by complementing thematic interview sessions with 241 employees of 67 software companies of Pakistan. The companies involved in the empirical study have reasonable years of experience in practicing Agile and Lean techniques. Generally, the obtained results depict that the usage of Kanban techniques is rather positive and appreciative; however, the challenges that are being faced in Kanban adoption are lack of specialized training and experience pertaining to its usage, and a too conventional organizational culture.
\end{abstract}

Keywords: Agile, Kanban, Lean, Muda, Software Development

\section{Introduction}

Nowadays, the Agile and Lean techniques are being extensively and successfully implemented in different industries across the globe. The Lean manufacturing / maintenance techniques were developed and implemented in manufacturing industries in different parts of the world [1] and subsequently found effective in producing the desired results. Later on, the Lean techniques were also adopted by the software development firms.
The primary function of Lean technique is to eliminate the waste or non-value-added activity from the line of process before it hampers the development / production. The authors of [1] transformed the Lean techniques for appropriate usage in software development realm. They proposed the following six set of principles:

- Creation of Quality

- Creation of Knowledge

- Commitment Deferment

\footnotetext{
${ }^{1}$ Department of Computer Science, Virtual University of Pakistan Lahore, Pakistan Corresponding Author: MS150400221@vu.edu.pk
} 
Muhammad Noman Riaz. Implementation of Kanban Techniques in Software Development Process: An Empirical Study Based on Benefits and Challenges

- Fast Delivery

- People Respect

- Optimization of the whole

In the context of software development any activity that does not contribute anything significant is termed as "Muda" or "Waste". For example, additional required processes, partially completed tasks, additional unwanted features, defects and units, untimely switching of tasks are considered as "Wastes" [1].

Kanban is one of the ways of implementing Lean technique that has been is usage in the management of production operations at Toyota Company for decades [2]. Kanban is one of the most recent additions in Lean and Agile software development methodologies. During the last few years the Kanban has become increasingly popular in the software development. A very powerful practitionersdriven movement emerged in its support [3], [4]. Presently, the Kanban approaches are confidently used by the software engineering practitioners to complement Agile, Scrum and other methodologies in software development processes.

However, despite the increasing popularity and increasing usage in software development, the present literature has failed to highlight the Kanban techniques appropriately in the context of software development. Only, a few numbers of studies on the usage of Kanban, how it can be effectively practiced, and its potential impact on the software development have been published [5]. With the aim of providing the latest status of Kanban usage and its impact on the software development and subsequent reputation of software companies, an empirical study has been conducted. The study encompasses 241 software engineering professionals belong to 67 software companies registered with Pakistan Software Export Board (PSEB). The survey has been conducted followed by interviews with high profile software engineering professionals working in Pakistan. The interviews addressed the following questions:
- What actually the benefits the Kanban technique is capable of providing?

- What are the potential challenges that the organization(s) may face in its adoption?

- What are appropriate solutions in addressing the Kanban usage challenges? The rest of the paper is organized as follows: Section II presents the literature review on the usage of Kanban technique. Section III describes the research settings that include the data collection process as well as the design of survey and complementing interviews. Section IV elaborates the obtained results and compares them with the findings and results of previously conducted research. The last section, Section V concludes the paper while summarizing the obtained results and discussing the limitations of the conducted research.

\section{Background of Kanban}

The Lean technique, Kanban, was first introduced in $1950 \mathrm{~s}$ by one of the senior executives, Mr. Taichi Ohno, of Toyota Company in the Japanese manufacturing industry. Literally, the term Kanban means the signboard or visualization of inventory items or system used in the scheduling system for Just in Time (JIT) production. The main reason behind the development of Kanban technique was to find and propose a system that guarantees the maintenance and improvement in the production system. Kanban is basically a flow driven mechanism for pull-driven JIT production, in that the upstream processing items / activities are triggered by the downstream process demand signals [2], [7]. The Kanban technique has been proven as production improvement technique and guarantees the smooth running of production system. The Kanban technique was successfully implemented and practiced in Toyota Production System (TPS) and the main reason of implementing Kanban at TPS was to execute the entire range of Lean manufacturing practices in length and breadth 
Muhammad Noman Riaz. Implementation of Kanban Techniques in Software Development Process: An Empirical Study Based on Benefits and Challenges (pp. 25 - 36)

of TPS as Lean is more than the Kanban technique [7], [8], [9].

In today's industry of software development, the appreciation of Lean and Kanban is hugely driven by practitioners' books [1], [6], [10]. Both the Lean and Kanban principles seem to immensely overlapping and hence depict the same foundation. The Table 1 below depicts the Lean principles of software development [1], [20] and Kanban principles [10], which are familiar to the Agile community.

Table I. Lean and Kanban Principles

\begin{tabular}{|l|l|}
\hline $\begin{array}{l}\text { Lean Software } \\
\text { Development } \\
\text { Principles [20] }\end{array}$ & $\begin{array}{l}\text { Kanban Principles } \\
{[\mathbf{2 0 ]}}\end{array}$ \\
\hline Waste Elimination & $\begin{array}{l}\text { Work flow } \\
\text { Visualization }\end{array}$ \\
\hline Build Quality in & $\begin{array}{l}\text { Limit Work in } \\
\text { Progress }\end{array}$ \\
\hline $\begin{array}{l}\text { Knowledge } \\
\text { Creation }\end{array}$ & $\begin{array}{l}\text { Measurement and } \\
\text { Management of } \\
\text { Flow }\end{array}$ \\
\cline { 1 - 1 } $\begin{array}{l}\text { Commitment } \\
\text { Deferment }\end{array}$ & $\begin{array}{l}\text { Explicit Process } \\
\text { Policy Making }\end{array}$ \\
\cline { 1 - 1 } Fast Delivery & Improvement via \\
\cline { 1 - 1 } People Respect & \\
\cline { 1 - 1 } Optimize the Entire & \\
\hline
\end{tabular}

In the year 2004, a software development professional, David J. Anderson, proposed an idea of implementing a Kanban technique in the software development when he was involved in assisting an IT team at Microsoft which was operating at below par level [10]. While assisting the project, David J. Anderson [10], introduced and urged upon the usage of Kanban technique to the members of IT team and asked them to visualize their activities and put limits on their Work in Progress (WIP). The main objective behind visualizing the activities and put certain limits on WIPs was the identification of constraints in the process (es) and to remain focus on one single activity / item at a time. As a result, the "Pull" approach has promoted. In a conventional software development process, each team member or a small group of members have to complete the tasks in stipulated time and forward it the next person or group in line i.e. the items are "pushed" towards the next responsible person / team who are directed to complete the forwarded / pushed tasks as early as possible and as maximum as possible. In fact this form of working style is basically a "chain" type in which the items are forwarded to next level in sequence i.e. from development to testing. This traditional style of software development has an inherent tendency of injecting delays in the entire software development process especially when the next responsible individual or group is overwhelmed with amount of work. However, the Kanban technique works in the other way. Rather than promoting the "push" approach i.e. pushing the items in sequence to the next level it promotes a "pull" concept. In Kanban approach, each team member/group works on one single item at a time and when that in hand task is completed only then the individual / group "pull" another item / task to work on.

In short, the Kanban technique is responsible to provide the visibility of software development process, disseminate priorities and identify bottlenecks [5]. This guarantees the constant distribution of work items to the stakeholders / customers. In this the developers only involved in those small items which are worthy for the customer [6]. The figure 1 below depicts a typical structure and principles of Kanban board in practice.

The incorporation of Kanban technique in software development process assists the software developers in highlighting their current tasks, the current work flow, limiting the WIP at each stage of work flow, and in measuring the cycle time [11]. The primary objective of Kanban is to remain focus on the present work flow and ensure the absence of essential iterations. 


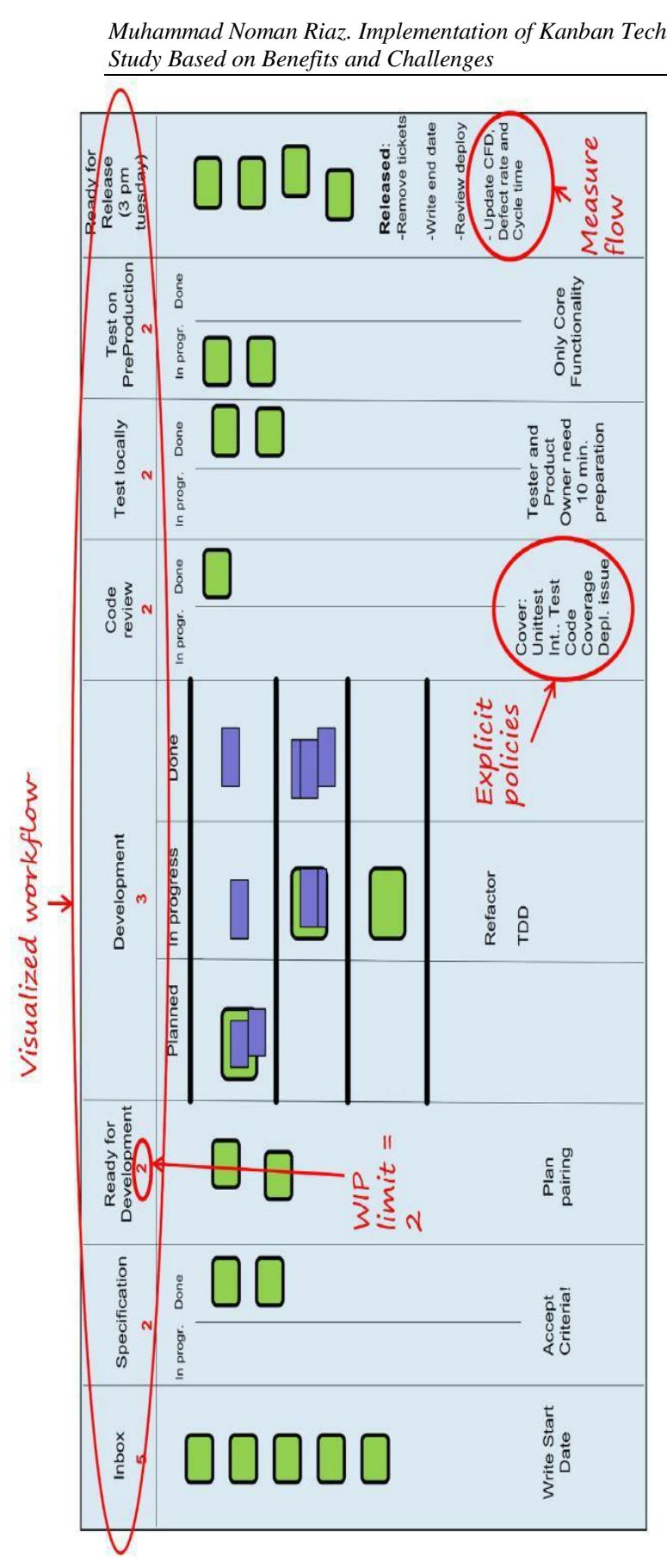

Fig 1. Kanban Structure and Principles Board in Practice [12], [20]
The practice of Kanban usage in manufacturing industries has yielded many fruitful results and advantages. The strong and successful historical data of Kanban implementation has urged the software developers to incorporate Kanban technique in software development and as a result the usage of Kanban technique has won the confidence of software development professionals and has gained well-built practitioners-driven support for its adaptation.

The Kanban technique is software industry was proliferated with boom after the publication of two well-known books [10], [12]. One of these books was authored by David J. Anderson with a title of "Kanban" [10]. In this book the author elaborated the concepts of Kanban in the development of software and systems. The other book was authored was Corey Lada and entitled, "Scrumban" [12], in the book the author discussed the fusion of Kanban and Scrum techniques.

The literature review [6] conducted in Kanban techniques few years ago revealed several challenges and benefits in the adaptation of Kanban technique in software development industry. Few of the benefits that the implementation and practice of Kanban technique guarantees include: the Kanban technique makes easier the understanding of whole development process, helps in augmenting the level of coordination and confidence among team members and project / production stakeholders, and facilitates the development team in understanding the requirements and satisfaction of the customers [14], [15], [16]. According the study [17], It was revealed that the Kanban technique has significantly improved the performance of the development teams, increased the customer satisfaction level and reduced the number of defects in the product. As compare to the previously used Agile method the lead-time of software development increased by $37 \%$, 
Muhammad Noman Riaz. Implementation of Kanban Techniques in Software Development Process: An Empirical Study Based on Benefits and Challenges (pp. 25 - 36)

delivery consistent rate increased by $47 \%$ and the number of customers reported defects have fallen by $24 \%$ [17]. Due to the WIP limits, the items that are of higher priority and need to be executed / developed earlier than the other items approach are pulled to optimize the value, that resulted in enhanced customer satisfaction level [14], [15], [17]. Another advantage of Kanban technique is that it does not the encourage the cramming of user requirements because the Kanban technique does not follow the fixed plan [21].

According to the results of [22], to work more effectively the Kanban technique needs to be implemented / practiced with other Agile techniques. But the fusion of Agile and Kanban techniques has a tendency of generating problems for some teams [18]. To encourage and motivate the developers to use Kanban has been a challenging task mainly due to organizational culture and stickiness and reluctance of software developers who are more comfortable and experienced in other similar development methodologies [16], [18], [23]. Besides this, the lack of specialized skills and adequate training, and misapprehension of core principles have significantly contributed in adoption Kanban technique [14], [16], [18], [24], [25].

\section{Research Settings}

The empirical data for study were collected from the professionals of volunteered participating companies. This empirical study was successfully conducted in two different stages. In the first stage of the survey, the usage of Kanban technique was carried out among the participating companies. During the survey the Internet Survey Tool was utilized. During the survey the questions were encompassing the usage of Kanban, the benefits achieved and associated with the usage of Kanban, motivation and reason to implement Kanban in the development and the challenges that create obstacle in the adoption of Kanban technique.

During the second stage of the survey, the thematic semi-structured interview sessions of 65-85 minutes duration were conducted with the volunteered survey respondents. These interview sessions roamed around the benefits that the practicing organizations are reaping and the challenges they are facing in the adoption of Kanban. The detailed discussions were carried out with the respondents in which the probable solutions of addressing the challenges of Kanban adoption were shared vividly by the respondents.

In the first stage of the survey, an Internet Survey Tool was used and the requests were sent to the hand-picked professionals of 67 software companies operating in Pakistan and registered with Pakistan Software Export Board (PSEB). The reason for sending the emails to the selected software professionals was to identify and rate the significance of Kanban usage, the motivation behind its usage, and the benefits achieved and the challenges faced in Kanban adoption. A fivepoint Likert scale was used during the survey to rate the received responses. During the survey a total of 241 persons representing 67 software companies responded to the survey questionnaire.

During the second stage of the survey, a total of 67 managerial level professionals of 67 software companies were individually interviewed. The primary reason of these interview sessions was to complement the first stage responses of the volunteers on Kanban usage. The duration of interview sessions was between 65 and 95 minutes with an average time of 75 minutes. All the interview sessions were recorded and transcribe by the interviewers, and to ensure consistency the transcripts were thoroughly checked by the individual interview. 
Muhammad Noman Riaz. Implementation of Kanban Techniques in Software Development Process: An Empirical Study Based on Benefits and Challenges

\section{Results}

In this section, the results obtained after the conduct of survey and semi-structured interview sessions are being presented and subsequently compared with the results of earlier conducted studies on Kanban usage in software industry.

\section{A. Survey Results}

The Table II and Table III below depict the appointments / positions and the level of experience the volunteered respondents of the survey possess in software development.

Table II. Interviewees background

\begin{tabular}{|l|l|}
\hline Appointments & $\mathrm{n}$ \\
\hline President / CEO & 35 \\
\hline CTO / VP / GM / Prog Manager & 45 \\
\hline $\begin{array}{l}\text { Product Owner / Product } \\
\text { Manager }\end{array}$ & 55 \\
\hline Scrum Trainer / Agile Coach & 60 \\
\hline $\begin{array}{l}\text { Software Analyst / Designer / } \\
\text { Developer }\end{array}$ & 25 \\
\hline Coach / Trainer / Consultant & 15 \\
\hline Software Programmer & 06 \\
\hline Total & 241 \\
\hline
\end{tabular}

Table III. Software development experience

\begin{tabular}{|l|c|c|}
\hline No of Years' Experience & $\mathrm{n}$ & $\%$ \\
\hline $1-5$ & 06 & 2.5 \\
\hline $6-10$ & 100 & 41.5 \\
\hline $11-15$ & 55 & 23 \\
\hline $15-20$ & 45 & 19 \\
\hline More than 20 & 35 & 14 \\
\hline Total & 241 & 100 \\
\hline
\end{tabular}

The volunteered respondents of the survey are working on different managerial levels in their respective organizations. Most of the respondents are working at mid-level management (Program Managers, Project Managers, Software Analysts, Agile Coaches etc.) and $86 \%$ of them possess more than 10 years of software development experience. The typical project team sizes in practice in the participating organizations are depicted below in Table IV.

Table IV. Teams size

\begin{tabular}{|l|l|l|}
\hline Teams Size & $\mathrm{n}$ & $\%$ \\
\hline $1-4$ & 17 & 25 \\
\hline $5-8$ & 15 & 23 \\
\hline $9-12$ & 23 & 34 \\
\hline $13-15$ & 10 & 15 \\
\hline 15 and greater & 2 & 3 \\
\hline Total & 67 & 100 \\
\hline
\end{tabular}

From the survey it was noticed that most of the project teams comprise of less than 10 professionals only. There are only two software development companies that have teams comprising more 13 professionals.

While performing the data analysis of the survey it was revealed by approximately $67 \%$ of the respondents that a Kanban technique is being used in their organization for managing the software development processes. Most of the Kanban practicing organizations that are included in the survey had been practicing Kanban for more than two years. Also, the software development professionals working in these organizations have considered themselves proficient and expert in implementation of Kanban technique.

During the interview sessions with the volunteered respondents, several questions were asked that encompassed the motivational factors of using Kanban technique, benefits achieved by the practicing organizations and the challenges associated with the Kanban. The results are depicted in Table V-VII based on the responses of the subjects. 
Muhammad Noman Riaz. Implementation of Kanban Techniques in Software Development Process: An Empirical Study Based on Benefits and Challenges

Table V. Motivational factors in using Kanban

\begin{tabular}{|l|c|c|}
\hline $\begin{array}{l}\text { Motivation for } \\
\text { Selecting Kanban } \\
\text { Method }\end{array}$ & $\begin{array}{c}\text { Med } \\
\text { ian }\end{array}$ & $\begin{array}{c}\text { Me } \\
\text { an }\end{array}$ \\
\hline $\begin{array}{l}\text { Improvement in Team } \\
\text { Communication }\end{array}$ & 5.4 & 6 \\
\hline $\begin{array}{l}\text { Improvement in } \\
\text { Development Flow }\end{array}$ & 5.2 & 6 \\
\hline $\begin{array}{l}\text { Reduction in } \\
\text { Development Cycle } \\
\text { Times \& Time-to- } \\
\text { Market }\end{array}$ & 5.1 & 5 \\
\hline $\begin{array}{l}\text { Productivity } \\
\text { Enhancement }\end{array}$ & 5.1 & 5 \\
\hline $\begin{array}{l}\text { Creation of } \\
\text { Transparency in } \\
\text { Organization }\end{array}$ & 4.8 \\
\hline $\begin{array}{l}\text { Improvement in Service } \\
\text { \& Product Quality }\end{array}$ & 4.8 & 5 \\
\hline $\begin{array}{l}\text { Comprehension of Entire } \\
\text { Value Stream }\end{array}$ & 4.5 & 5 \\
\hline $\begin{array}{l}\text { Improvement of Process } \\
\text { Quality }\end{array}$ & 4.5 & 5 \\
\hline $\begin{array}{l}\text { Augmenting Satisfaction } \\
\text { of Stakeholders }\end{array}$ & 4.3 & 5 \\
\hline $\begin{array}{l}\text { Elimination of Excess } \\
\text { Activities }\end{array}$ & 4.3 \\
\hline $\begin{array}{l}\text { Nurturing the Ability to } \\
\text { Adapt to Changes in } \\
\text { Business Arena }\end{array}$ & 4.8 \\
\hline $\begin{array}{l}\text { Reduction in } \\
\text { Development Costs }\end{array}$ & 4.6 \\
\hline $\begin{array}{l}\text { Improvement in } \\
\text { Organizational Learning }\end{array}$ & 4 \\
\hline $\begin{array}{l}\text { Management of Product } \\
\text { Value }\end{array}$ & 3.5 \\
\hline $\begin{array}{l}\text { Increased Customer } \\
\text { Understanding / Trust }\end{array}$ & 4 \\
\hline
\end{tabular}

The above table clearly depicts that the highest motivation factors in the adaptation of Kanban technique is the effective communication between the team members working on a similar project as well between the teams working on different task of similar project. Also, the usage of Kanban technique encourages the reduction in product development life cycle and the time-tomarket the product, helps in improving the flow of product development and bolsters the productivity of the organization [25]. Besides guaranteeing the aforementioned advantages the Kanban technique most importantly ensures the transparency within the organization. According to the research of the authors [11], the implementation of Kanban technique is highly motivated by its ease of adaptability; its visualization style of monitoring the progress creates easiness for the workers [26], and drives the project team members to effectively and efficiently communicate with each other during the project. As far as the software development is concerned the motivation factors are aligned with what Anderson elaborated [10], [27].

During the interview sessions the subjects / respondents were also asked to indicate the benefits achieved by their respective organizations. The achieved benefits of the organizations are presented below in Table VI.

Table VI. Benefits Achieved by Organizations After Using Kanban Method

\begin{tabular}{|l|c|c|}
\hline \multicolumn{1}{|c|}{ Benefits Achieved } & $\begin{array}{c}\text { Media } \\
\text { n }\end{array}$ & $\begin{array}{c}\text { Mea } \\
\text { n }\end{array}$ \\
\hline Excellent Work Visibility & 6 & 5.9 \\
\hline $\begin{array}{l}\text { Better Transparency in } \\
\text { Work }\end{array}$ & 6 & 5.5 \\
\hline $\begin{array}{l}\text { Better Communication } \\
\text { between Team Members / } \\
\text { Teams }\end{array}$ & 5 & 5.3 \\
\hline $\begin{array}{l}\text { Improved Development } \\
\text { Flow Control }\end{array}$ & 5 & 5.2 \\
\hline $\begin{array}{l}\text { Improved Focus on } \\
\text { Routine Work Activities }\end{array}$ & 5 & 5.1 \\
\hline
\end{tabular}


Muhammad Noman Riaz. Implementation of Kanban Techniques in Software Development Process: An Empirical Study Based on Benefits and Challenges

\begin{tabular}{|l|c|c|}
\hline $\begin{array}{l}\text { Improved Control on } \\
\text { Work In Progress (WIP) }\end{array}$ & 5 & 5.0 \\
\hline $\begin{array}{l}\text { Improved Team } \\
\text { Efficiency }\end{array}$ & 5 & 4.9 \\
\hline Better Risk Management & 5 & 4.7 \\
\hline $\begin{array}{l}\text { Improvement in the } \\
\text { Comprehension of Entire } \\
\text { Development Process }\end{array}$ & 5 & 4.6 \\
\hline $\begin{array}{l}\text { Beneficial in Building } \\
\text { Team Trust }\end{array}$ & 5 & 4.6 \\
\hline Assists in Inevitability & 5 & 4.5 \\
\hline $\begin{array}{l}\text { Decrement in Switching } \\
\text { of Environment }\end{array}$ & 4 & 4.5 \\
\hline Improvement in Quality & 4 & 4.1 \\
\hline $\begin{array}{l}\text { Assistance in Strategic } \\
\text { Decision Making for } \\
\text { Organizational Leadership }\end{array}$ & 4 & 3.7 \\
\hline Better Knowledge Sharing & 5 & 5.2 \\
\hline $\begin{array}{l}\text { Better Stakeholder } \\
\text { Management }\end{array}$ & 4 & 4.2 \\
\hline $\begin{array}{l}\text { Improved Employee } \\
\text { Motivation }\end{array}$ & 5 & 4.8 \\
\hline Reduced Job Turn Over & 5 & 5.1 \\
\hline $\begin{array}{l}\text { Improved Inventory } \\
\text { Management }\end{array}$ & 4 & 4.6 \\
\hline $\begin{array}{l}\text { Elimination of } \\
\text { Overproduction }\end{array}$ & 5 & 4.9 \\
\hline $\begin{array}{l}\text { Decreased Risk of } \\
\text { Inventory Devolution }\end{array}$ & 5 & 5.6 \\
\hline $\begin{array}{l}\text { High Level of Employee } \\
\text { Empowerment }\end{array}$ & 5.7 \\
\hline Better Quality Control & 5 \\
\hline $\begin{array}{l}\text { Smooth Development } \\
\text { Flow }\end{array}$ & 5 & \\
\hline
\end{tabular}

Improved Visibility of Routine Work, Enhanced Transparency pertaining to Team Communication and Better Control of Work Flow. All these common experienced benefits (except that of Better Risk Management and Better Knowledge Sharing among the team members / teams) are also highlighted in the literature [4], [6], [10], [12], [19], [27].

Moreover, during the interview sessions the respondents / subjects were asked to identify the challenges that they and their organizations are facing in the implementation of Kanban technique in true letter and spirit. The reasons the respondents identified are listed in order of significance in Table VII.

From the results it has been concluded that the main hurdle in the implementation of Kanban technique in software development is employees' lack of experience in practicing Kanban technique. The other identified challenges in the usage of Kanban are difficulty in prioritizing the workload / tasks of the ongoing projects and management of Work in Progress (WIP) limits. The traditional organizational culture and no clear road map for future development are also the major contributing factor in non-practicing of Kanban method. We can easily and confidently infer from the above discussion that all these challenges are simply associated with one problem: a scarcity of adequate knowledge and specialized training.

The Table VI above depicts that the most of the benefits achieved by the organizations are almost the same as revealed in the available literature except that of Better Risk Management and Better Knowledge Sharing among the team members / teams. The most common benefits experienced by the subjects / respondents were Better Knowledge Sharing, Better Knowledge Sharing, 
Muhammad Noman Riaz. Implementation of Kanban Techniques in Software Development Process: An Empirical Study Based on Benefits and Challenges

Table VII. Kanban Implementation Challenges

\begin{tabular}{|l|l|l|}
\hline $\begin{array}{l}\text { Kanban } \\
\text { Implementation } \\
\text { Challenges }\end{array}$ & $\begin{array}{l}\text { Medi } \\
\text { an }\end{array}$ & $\begin{array}{l}\text { Me } \\
\text { an }\end{array}$ \\
\hline $\begin{array}{l}\text { Employees Lack of } \\
\text { Experience in Practicing } \\
\text { Kanban }\end{array}$ & 5 & 5.0 \\
\hline $\begin{array}{l}\text { Difficulty in Managing } \\
\text { Work In Progress (WIP) } \\
\text { Limits }\end{array}$ & 5 & 4.9 \\
\hline $\begin{array}{l}\text { Difficulty in Prioritizing } \\
\text { Tasks }\end{array}$ & 4 & 4.3 \\
\hline $\begin{array}{l}\text { Traditional } \\
\text { Organizational Culture }\end{array}$ & 4 & 4.2 \\
\hline $\begin{array}{l}\text { Dearth in Specialized } \\
\text { Training \& Knowledge }\end{array}$ & 4 & 4.1 \\
\hline $\begin{array}{l}\text { Lack of Vision in } \\
\text { Product Development }\end{array}$ & 4 & 4.0 \\
\hline $\begin{array}{l}\text { Team Members } \\
\text { Reluctant to Switch from } \\
\text { Traditional Methods }\end{array}$ & 4 & 3.9 \\
\hline $\begin{array}{l}\text { Inefficiency in Decision } \\
\text { Making }\end{array}$ & 4 & 3.6 \\
\hline $\begin{array}{l}\text { Absence of } \\
\text { Developer/Customer } \\
\text { Collaboration }\end{array}$ & 4 & 3.5 \\
\hline $\begin{array}{l}\text { Lack of Planning in } \\
\text { Adoption of Kanban } \\
\text { Technique }\end{array}$ & 4 & 3.4 \\
\hline $\begin{array}{l}\text { Absence of Sponsorship } \\
\text { from Organizational } \\
\text { Management }\end{array}$ & 4 & 3.4 \\
\hline $\begin{array}{l}\text { Reduction in } \\
\text { Predictability }\end{array}$ & 3.4 \\
\hline $\begin{array}{l}\text { Team Members / Teams } \\
\text { Feel Burden of } \\
\text { Communication }\end{array}$ & 4 & 3.3 \\
\hline $\begin{array}{l}\text { Reluctance shown by } \\
\text { Customers for Increased } \\
\text { Communication }\end{array}$ & 3 & 3.2 \\
\hline $\begin{array}{l}\text { Kanban Method and } \\
\text { Business Domain } \\
\text { Incompatibility Issue }\end{array}$ & 3 & 2.9 \\
\hline
\end{tabular}

\begin{tabular}{|l|l|l|}
\hline $\begin{array}{l}\text { Reluctance in Adoption } \\
\text { from Old Employees }\end{array}$ & 3 & 2.7 \\
\hline $\begin{array}{l}\text { Lack of Experience in } \\
\text { Kanban Usage }\end{array}$ & 3 & 2.9 \\
\hline
\end{tabular}

\section{B. Results of Interview Sessions}

In this sub-section the results obtained from the conducted interview sessions are elaborated. The obtained results have been categorized in three main themes: obtained benefits, challenges faced by the organizations, and the appropriate solutions in countering these Kanban implementation challenges.

\section{1) Obtained Benefits}

Majority of the respondents communicated that the Kanban works extremely well within the teams of their organizations. During the interview sessions of the interviewees mentioned one of the benefits that he has experienced while practicing the Kanban is, "One of the main benefits that we in our organization have experienced is that the customer feedback loop has enhanced". In connection with the obtained survey results the respondents have also revealed the impact of Kanban usage in team work. One of the interviewees quite confidently revealed that, "Kanban has brought life to our projects and relationships. Team members rather than focusing on the end results, we as team members, focused us on the ongoing processes. This helps us in finding the balance between the customer demand and our capabilities". Also, one of the interviewees elaborated that Kanban has benefited us in our "Testing System", he said, "A Kanban adoption has proved beneficial for us because it assists us in limiting the tasks after its release and we get some time to explore the mistakes we committed while performing these tasks. In this manner the things or difficulties that were unable to be found are being found easily and hence the number of 
Muhammad Noman Riaz. Implementation of Kanban Techniques in Software Development Process: An Empirical Study Based on Benefits and Challenges (pp. $25-36)$

bugs per release has been decreased manifold".

Furthermore, all the interviewees were of the view that the usage of Kanban technique in the software development that it makes the team collaboration visible and even more amount of work can be completed collectively with less cost and difficulty. One of the respondents claimed, "The use of Kanban technique helps in strengthen the bonding between the team members and hence helps in achieving the desired results easily". Another respondent revealed, "A Kanban technique helps those workers who have trouble in performing their tasks in a way that other workers assist them collectively". Furthermore, it was identified by another interviewee, "The team members collaboratively and collectively start finding where the things have been stuck and what would be the probable cause of this stagnation and make every endeavor to troubleshoot the obstacles that are present in the flow of working”. Additionally, one interviewee mentioned, "A Kanban technique ensures the organization of work with flexibility and efficiency".

\section{2)Challenges Faced by the Organization in the Usage of Kanban Technique}

During the survey it was found out that the biggest challenge the organizations are facing the implementation of Kanban technique is that the employees are having no prior Kanban practicing experience, and that deficiency leads to other challenges that include difficulty in prioritizing the in-hand tasks and the management of WIP limits etc. In this context, one of the interviewees explained with heavy heart, "Unfortunately, in our company, not many of the professional software engineers / developers are having prior working knowledge of Kanban technique. Also, those have the requisite skills and experience in the implementation of
Kanban also feels under confident in adopting the Kanban technique in the organization. Furthermore, there are people in our organization who are resistant to change and do not want the adaption of Kanban in software development".

Furthermore, another respondent revealed, "Actually the upper management is reluctant to introduce Kanban in our organization. The main reason for discouraging the usage of Kanban is that upper management has no confidence in the abilities of Kanban. They are of the view that if the experiment of using Kanban fails then that will surely lead to loss of market share".

Another respondent reported, "One of the biggest challenges that we are facing in the implementation of Kanban in our organization is that of a lack of knowledge and expertise of using Kanban in software development. Nobody is sure of using Kanban technique in software development both at team as well as a portfolio level. The employees usually ask a question, What is in it (Kanban technique) for us? And unfortunately, no one in our organization has answered this question with confidence".

Furthermore, besides requiring the adequate knowledge and specialized training, a positive approach or mind-set is an essential requirement in adopting and implementing any new concept. Without an adequate knowledge and experience it would be difficult to motivate the workforce for using the Kanban technique in their routine software development activities. This thing also compels the teams to revert to their previously adopting methodology / approach. In this context one of the respondents replied, "It takes a lot of time and efforts to change the mature mind-set of staunch traditionalists".

\section{3) Proposed Solutions to the Challenges}

During the interview sessions the respondents were asked about the possible and probable

Sukkur IBA Journal of Computing and Mathematical Science - SJCMS | Vol. 3 No. 2 July - December 2019 @ Sukkur IBA University 
Muhammad Noman Riaz. Implementation of Kanban Techniques in Software Development Process: An Empirical Study Based on Benefits and Challenges (pp. 25 - 36)

solutions of the Kanban usage challenges. Based on the survey, the following solutions have been proposed by the respondents to mitigate the Kanban usage challenges.

- An adequate training and exposure to the usage of Kanban in software development must be provided to the software developers and managers

- It is recommended that the teams must allow to experiment or start a pilot project of small-scale to gain hands on experience in Kanban usage

- The upper management of the organization must take every possible step to change the mind-set of the employees. This will surely help in minimizing the opposition of Kanban usage

- Appropriate number of seminars must be conducted in regular intervals to promote the use of Kanban

\section{Conclusion}

During the study it was revealed that the main motivational factors that contribute in the usage of Kanban technique are; the effective communication between teams and team members, reduced time for the product to access the market, enhanced productivity, better risk management and knowledge sharing, and creation of transparency within the organization. Despite the limited scope of study, however, this study provides the valuable contemporary state of the usage of Kanban technique in software companies of Pakistan. This study significantly contributes in providing firsthand information of Kanban usage in software industry of Pakistan. Also, the ground realities and challenges that being faced by the software practitioners in Pakistan software industry have been bluntly and candidly discussed by the interviewees. Lastly, this study will provide a solid foundation for further exploring the challenges and their probable solutions in implementing Kanban technique in software development companies of Pakistan.

\section{REFERENCES}

[1] M. Poppendieck and T. Poppendieck, Lean Software Development: An

Agile Toolkit, Addison-Wesley Professional, 2003.

[2] J. Liker, The Toyota Way, USA: McGraw-Hill, 2004.

[3] K. Hiranabe, Kanban applied to software development: From agile to lean, InfoQ. [Online] Available from: http://www. infoq. com/articles/hiranabe-lean-agilekanban 2014.05.04

[4] A. Shalloway, B. Guy, and R. James Trott, Lean-agile Software Development: Achieving Enterprise Agility, Pearson Education, 2009.

[5] Cloud Software Finland, General Brochure. [Online] Available from: http://www.n4s.fi/en/, http://www.cloudsoftwareprogram.org/g eneral-brochure 2014.05.13

[6] M. O. Ahmad, J. Markkula, and M. Oivo, "Kanban in Software Development: A Systematic Literature Review," 39th Euromicro Conference on Software Engineering and Advanced Applications (SEAA), 2013, pp. 9-16.

[7] L. Chai, "E-based Inter-enterprise Supply Chain Kanban for Demand and Order Fulfilment Management," International Conference on Emerging Technologies and Factory Automation, 2008, pp. 33-35.

[8] M. Becker and H. Szczerbicka, "Modeling and Optimization of Kanban Controlled Manufacturing Systems with GSPN including QN," International Conference on Systems, Man, and Cybernetics, 1998, vol. 1, pp. 570-575.

[9] M. Ikonen and P. Abrahamsson, "Anticipating Success of a BusinessCritical Software Project: A Comparative Case Study of Waterfall and Agile 
Muhammad Noman Riaz. Implementation of Kanban Techniques in Software Development Process: An Empirical Study Based on Benefits and Challenges (pp. $25-36)$

Approaches", In Proc. ICSOB, 2010, pp. 187-192.

[10]D. Anderson, Kanban - Successful Evolutionary Change for Your Technology Business. Blue Hole Press, 2010.

[11] H. Kniberg and M. Skarin, "Kanban and scrum - Making the most of both," InfoQ, 2010.

[12] C. Ladas, Scrumban - Essays on Kanban Systems for Lean Software Development, Modus Cooperandi Press, 2009.

[13] J. Boeg, Priming Kanban, A 10 Step Guide to Optimizing Flow in Your Software Delivery System, Trifork Agile Excellence Mini Book Series, $2^{\text {nd }}$ ed., Denmark at Chronografisk A/S, 2012.

[14] M. Senapathi, P. Middleton, and G. Evans, "Factors Affecting Effectiveness of Agile Usage - Insights from the BBC Worldwide Case Study," In Proc. XP, 2011, pp. 132-145.

[15] M. Ikonen, E. Pirinen, F. Fagerholm, P. Kettunen, and P. Abrahamsson, "On the Impact of Kanban on Software Project Work: An Empirical Case Study Investigation," In Proceedings of ICECCS, 2011, pp. 305-314.

[16] N. Nikitina and M. Kajko-Mattsson, "Developer-driven big-bang process transition from Scrum to Kanban," In Proceedings of ICSSP, 2011, pp. 159168.

[17] P. Middleton, and D. Joyce, "Lean software management: BBC Worldwide case study," IEEE Transactions on Engineering Management, 2012, vol. 59(1), pp. 20-32.

[18] V. G. Stray, N. B. Moe, and T. Dingsøyr, "Challenges to Teamwork: A Multiple Case Study of Two Agile Teams," In Proceedings of XP, 2011, pp. 146-161.

[19]M. O. Ahmad, K. Liukkunen, J. Markkula, "Student perceptions and attitudes towards the software factory as a learning environment," In Proceedings of IEEE EDUCON, 2014, pp. 422,428.
[20] Ahmad, M. O., Markkula, J., Oivo, M., \& Kuvaja, P. (2014, October). Usage of Kanban in software companies: an empirical study on motivation, benefits and challenges. In Proceedings of 9th International Conference on Software Engineering Advances.

[21] Kirovska, N., \& Koceski, S. (2015). Usage of Kanban methodology at software development teams. Journal of Applied Economics and Business, 3(3), 25-34.

[22][22] Hofmann, C., Lauber, S., Haefner, B., \& Lanza, G. (2018). Development of an agile development method based on Kanban for distributed part-time teams and an introduction framework. Procedia Manufacturing, 23, 45-50.

[23][23] Ahmad, M. O., Dennehy, D., Conboy, K., \& Oivo, M. (2018). Kanban in software engineering: A systematic mapping study. Journal of Systems and Software, 137, 96-113.

[24] [24] Tanner, M., \& Dauane, M. (2017). THE USE OF KANBAN TO ALLEVIATE COLLABORATION AND COMMUNICATION CHALLENGES OF GLOBAL SOFTWARE DEVELOPMENT. Issues in Informing Science \& Information Technology, 14.

[25][25] Hofmann, C., Lauber, S., Haefner, B., \& Lanza, G. (2018). Development of an agile development method based on Kanban for distributed part-time teams and an introduction framework. Procedia Manufacturing, 23, 45-50.

[26] [26] Ahmad, M. O., Dennehy, D., Conboy, K., \& Oivo, M. (2018). Kanban in software engineering: A systematic mapping study. Journal of Systems and Software, 137, 96-113.

[27][27] Lei, H., Ganjeizadeh, F., Jayachandran, P. K., \& Ozcan, P. (2017). A statistical analysis of the effects of Scrum and Kanban on software development projects. Robotics and Computer-Integrated Manufacturing, 43, 59-67. 